\title{
CX3CL1 wt Allele
}

National Cancer Institute

\section{Source}

National Cancer Institute. CX3CL1 wt Allele. NCI Thesaurus. Code C49753.

Human CX3CL1 wild-type allele is located within $16 q 13$ and is approximately $13 \mathrm{~kb}$ in

length. This allele, which encodes fractalkine precursor protein, plays a role chemotaxis, signal transduction and cellular adhesion. 